International Journal of Advanced Academic Research (Social and Management Sciences) | ISSN: 2488-9849 Vol. 6, Issue 12 (December, 2020)| www.ijaar.org

Journal DOI: 10.46654/ij.24889849

Article DOI: 10.46654/ij.24889849.s61230

\title{
INFLUENCE OF CONTINGENT PAY AND VARIABLE PAY ON EMPLOYEES PERFORMANCE OF PUBLIC TERTIARY INSTITUTIONS
}

\author{
Allison Pat., Ph.D \\ Department of Business Management, \\ Godfrey Okoye University, Enugu State, Nigeria \\ patukallison@yahoo.com \\ Okoli Ifeanyi .E. Nuel, Ph.D \\ Department of Entrepreneurial Studies, \\ Nnamdi Azikiwe University, Anambra State, Nigeria \\ ie.okoli@unizik.edu.ng \\ Nuel-Okoli, Chinenye Maureen \\ (Ph.D Student) Department of Business Administration, \\ Chukwuemeka Oduemgwu Ojukwu University, Anambra State, Nigeria \\ chinnynuel@yahoo.com
}

\begin{abstract}
This study was to examine the influence of contingent pay and variable pay on employee performance in selected public universities. The study was anchored on social exchange theory. A cross sectional survey research design was employed for the study. Stratified sampling techniques were used to obtain a sample of 354 out of a target population of 4658 using Krejcie and Morgan (1970) formula. Data were collected using a structured questionnaire. The study used expert judgment method to determine content validity. Data were analyzed using Pearson's product moment correlation coefficient at 5\% level of significance. The findings revealed that there was a significant positive relationship existing between contingent pay and altruism and there was a significant positive relationship existing between variable pay and employee retention. The study concluded that contingent pay and variable pay has a significant positive relationship with employee performance variables (altruism and employee retention) in the public universities studied. The study recommended that universities administration should take into account the performance of people when granting pay system, as this will help them to motivate employees to try their best and stay longer in organizations.
\end{abstract}

Keywords: Contingent pay, Variable pay, Performance, Altruism, Employee Retention. 
International Journal of Advanced Academic Research (Social and Management Sciences) | ISSN: 2488-9849

Journal DOI: 10.46654/ij.24889849

Vol. 6, Issue 12 (December, 2020) | www.ijaar.org

Article DOI: 10.46654/ij.24889849.s61230

\section{INTRODUCTION}

Organizations exist to produce goods or provide services or both in some cases. Achieving this depends on the employees and their level of commitment and commitment to the organization. In other words, employees are the basis of the very existence of any organization. There has been much literature to support this claim that employees are the most valuable asset available to any organization. The performance of employees in an organization is one of the topics that are most discussed in organizational research. Armstrong \& Murlis (2007) state that employee performance has been a concern for organizations in today's competitive environment, as it is now commonly accepted that employees create an important source of competitive advantage for companies. The willingness of employees to use their ideas, skills and knowledge influences the success of an organization (Tuvei, Wanjere \& Mauyo, 2016). In support of this position, Roshna \& Rohan (2016) emphasize that employees are the assets of the company and are the brainchild of all systems and live organizations.

Having recognized the important role played by employee, employees are now considered the backbone of corporate survival. The reward has to do with what employees receive in exchange for their contribution to an organization; it could be a form of positive reinforcement. It is what an employee expects to get after performing work in days, months or years in cash or in kind. Obisi (2003) sees the reward as an award given to employees as an incentive for their performance. It is the compensation that an employee receives from an organization in exchange for the service offered by the employee or as a return for the work performed (Zhou, Qian, Henan \& Lei, 2009). Korir \& Kipkebut, (2016) opine that rewards is one of the most indispensable elements to motivate employees to contribute with their best efforts in order to generate innovative ideas that lead to better commercial operations.

The reward in organizations covers financial and non-financial aspects, tangible and intangible aspects instead of the erroneous views that the reward has to do only with compensation. Reward systems are all monetary, non-monetary and psychological payments that an organization provides to its employees (Turinawe, 2011). Contingent pay and variable pay are kinds of reward that has become increasingly important for motivating employees to perform productively at work. Contingent pay (also called incentive) and variable pay are provisions where some or all employees pay based on certain performance. It may be determined by individual employees' performance in relation to their level of contribution to organizational performance (individual-based incentive), or profit gained by the organisation in which the employee works (organisation-wide incentive). Contingent pay and variable pay represents one of key elements of human resource management (HRM) systems aimed at achieving sustainable competitive success for an organization (Gould-Williams, 2003).

Many reasons are cited for why people decide to work in an organization like the public universities studied against working on their own or working in other sectors of the economy. Standing above any other reason, since existing literature argues is a reward; what employees can get in the form of wages, salaries, complementary benefits, incentives and other forms of emoluments and recognition. The contingent pay and variable pay are attractive and motivating factor in most organizations, of which Chukwuemeka Odumegwu Ojukwu University (COOU) Uli and Nnamdi Azikiwe University, (NAU) Awka, Anambra State are no exception. However, when the pay system and its 
management do not act as a positive factor in the organization, it is said that the pay system is defective or ineffective as it seems in the institutions studied. As a result of inadequate pay management system, universities have suffered low performance, low staff morale and high employee turnover. There seems to be problems of disparities in the treatment of different staff members from different departments or areas, since some non-teaching staff members in the medical and safety line receive payment for staying overtime and some of those in the laboratories they receive risk subsidies, while others do not. This is the main reason why there is currently a confrontation between the federal government and non-teaching staff. There is also a problem of study leave without pay, inability of the government to comply with contracts signed with nonteaching staff and their unions. All this is seen as an injustice by non-teaching staff and could affect their performance. It is in the context of these problems that this study was necessary to carry out an empirical study of the situation in order to determine how contingent pay and variable pay of the institutions studied affect the performance of employees that invariably affect the performance of the organization.

It is in the context of these problems that this study was necessary to carry out an empirical study of the situation in order to determine how effective are contingent pay and variable pay affects performance of employees of public institutions. Specifically, the study seeks to:

(a) Examine the nature of relationship existing between contingent pay and altruism in public universities in Anambra State, Nigeria.

(b) Ascertain the extent of relationship existing between variable pay and employee retention in public universities in Anambra State Nigeria.

\section{REVIEW OF RELATED LITERATURE}

\section{Contingent Pay}

Contingent pay is the type of payment that considers employee performance, skills, competencies, skills and knowledge before rewarding. Armstrong \& Murlins (2007) believe that contingency pay refers to any form of financial reward that is paid in cash as a bonus or added to the base rate and is linked to the performance, skills, competence and contributions of an employee to the organization. According to Njanja, Maina, Kibet \& Njagi (2013), organizations use contingency payment to reward their employees for meeting and exceeding established objectives. The amount of the contingency payment is determined based on the level of performance or the rank of the employee in the organization. In addition, it can be based on the professional development, competence and skill level of individual employees (Armstrong, 2012).

Contingent payment is made up of payments related to individual performance, gift, competence and skills or performance of the entire team/organization. It can be used to set performance standards in an organization. That is, to qualify for an additional payment, a certain standard must be achieved. Shield (2007) argues that contingent payment provides a means through which an organization can define and establish levels of expectations and performance. The strongest argument for contingent payment is the view that it is correct and appropriate that the employee's reward be derived from their performance, contribution, competence or skills, rather than being 
rewarded for "being at work", since it is still common in the public and voluntary sector, in the health and education system (Horváthová, Davidová \& Bendová, 2012).

Payment made based on skills, performance and competencies can be paid to individual performance or to equipment that exceeds others or meets established standards. Armstrong (2012) postulates that contingent payment provides financial benefits and rewards related to the individual, team or performance organization or a combination of these. However, the objective of this study is contingent payment based on equipment: According to Armstrong (2012), contingent payment could help:

a) Improve teamwork that will improve cooperative behaviour among team members.

b) Improving flexibility, multiple skill and integration of organizational and team objective.

c) Allow people who do not perform well to improve their game to meet team standards.

d) Develop self-managed or self-directed teams.

\section{Variable Pay}

Variable in ordinary language means being able to change, probably vary, tending to deviate from the normal recognized rate. It could also mean modifiable, flexible, changing and mutable. According to this, the variable payment is that payment that is flexible, changing from the norm and that can be varied. The base salary that is what employees are entitled to recently is losing their taste for the salary that takes into account the level of performance. Traditional payment systems have been reviewed in response to changing business objectives and new forms of work organization (Arrowsmith, Nicholaisen, Bechter, \& Nonell, 2010). As a result, performance compensation is growing in importance (Dale-Olsen, 2012). In this context, it is often stated that remuneration for performance or variable is fundamental for competitive organizations (Appelbaum \& Shapiro, 1991; Appelbaum \& Shapiro, 1992).

The variable payment is the payment that considers the individual performance considering that as the performance is met and exceeded, the salary also increases and exceeds the normal base salary. According to Heneman (2002), variable payment is a system that rewards employees for their outcomes in the industry. In this case, each individual or group of employees is reimbursed by the payment from the stimulus (Colling \& Terry, 2010). The variable pay is cash payments to people in the form of performance pay or bonuses based on their own performance or that of your team or organization (Armstrong \& Murlis, 2007). From the above, it can be seen that the variable payment can be divided into variable payment based on the equipment and individual variable payment. However, within the context of this study, the focus is on individual variable pay.

It is a payment strategy used to reward people for their performance and achievements in the organization. Michael \& Heneman (2000) state that organizations increasingly use variable pay plans to reward employees for the results they achieve. The variable payment not only rewards people for their good performance, but also tries to keep employees within the organization and attracts qualified people for competitive performance. Eriksson \& Villeval (2008) emphasize the link between pay and performance, but they can also help firms attract productive employees. The payment of employees does not depend solely on the jobs they have. Instead, organizations vary the amount paid according to differences in the performance of the individual, group or complete 
organization, as well as differences in the qualities of employees, such as seniority, educational levels and skills (Gerhart \& Milkovich, 1992).

\section{Employee Performance}

Aguinis (2007) opined that performance has to do with the behaviour or what employees do and not with what employees produce or the results of their work. It is the ability to download skills, work or acceptable tasks. It is action behaviour or an outcome that an employee must be able to demonstrate after acquiring knowledge, skills, attitudes, etc. of training (Mamoria, 1991). Hasim (2000) posit that the measure of employee performance is the determination of finances, profitability and growth attributed to the individual employee as a contribution to the company. For its part, Berridge (2001) argues that common measures of organizational performance such as profit margin, asset performance, capital return and sales performance can be attributed to each individual as a contribution. Kemboi, Geoffrey \& Keter (2014) stressed that the performance of an employee has become critically the essence and the value to achieve the goals and results of organizational performance; that is, the performance of the staff is linked to the overall performance of the organization.

\section{Altruism and Employee Retention as Dimensions of Employee Performance}

\section{Altruism}

Altruism is a discretionary or spontaneous behaviour of employees that aims to help co-workers complete their work on time to help boost the overall organization's performance. It is an act performed by employees voluntarily without being asked or forced to do so. Arachie (2016) states that the surprising thing in the definitions given by different researchers about the concept of altruism is that it has to do with an employee deciding on their own will, without being asked or forced to do so, to help others employees to carry out their organizationally recognized tasks. Obamiro, Oluseye \& Osibanjo (2014) state that altruism is a type of discretionary behaviour designed to help and motivate other employees in the efficient performance of their duties and to help others address work-related problems. Another important thing to keep in mind is that it is designed to help other employees carry out work-related activities that the ultimate goal is to push the organization to greater heights. Burns \& Carpenter (2008) affirm that altruism can be defined as behaviours of a discretionary nature that are aimed at helping people achieve organizationally assigned tasks. It involves helping specific individuals in relation to organizational tasks (Redman \& Snape, 2005).

Many acts carried out by the employees of an organization could be called altruistic behaviours or acts. For example, according to Arachie (2016), altruistic behaviours could be in the form of advice to an employee who is at a crossroads on how to perform a particular task, serving clients when an employee faces too many clients to serve them. , helping to carry out a difficult task that requires another person. Other forms of altruism in organizations are voluntarily helping new or less experienced staff and employees who have been busy or absent. Altruism or help co-workers makes the frame work is more competent and effective on the basis that a worker can use their free time (free time) to help his colleague in a more urgent task (Yen \& Neihoff, 2004). 


\section{Employee Retention}

Employee retention in the organization is one of the most herculean tasks of human resources management in organizations. This is because it is not easy to retain highly effective employees in a competitive market. Nnaji-Ihedinmah \& Egbunike (2015) state that in a globalized world characterized by competition, access to the latest technology and communication systems, and unrestricted access to financial markets around the world, the ability to attract and retain qualitative workmanship, as well as keeping them highly motivated has become a great challenge. This challenge can be successfully navigated through an appropriate reward system. Succinctly captured this Ejumudo (2011) believes that without adequate remuneration system, it is likely that employees today are going and will also be difficult to involve new people. The management of rewards is one of the strategies used by human resource managers to attract and retain suitable employees and provide them to improve their performance through motivation and comply with legislation and labour regulations (Njanja, et al, 2013).

Contingent pay and variable pay aim not only to attract employees but also to retain them in the organization. Korir \& Kipkebut (2016) posit that the strategic management of rewards of a firm should be designed to attract and retain the right employees to ensure that there is a direct relationship between pay and efforts. An organization's ability to attract and retain employees depends primarily on its reward package. The organizations use management contingent and variable pay to attract, retain and motivate its employees (Harzing \& Ruysseveldt, 2005). This is because there is a great implication of costs in the desertion or rotation of employees. It varies from the cost of recruitment, interruption of services and activity flows, the cost of training and lost time. Remuneration not only compensates employees for their efforts, but also has an impact on the recruitment and retention of talented people (Milkovich \& Newman, 2001).

Felps, Mitchell, Hekman, Lee, Holtom \& Harman (2009) opined that as global economies become stronger based on knowledge, groups that can retain their human resources are more valuable than less powerful companies. Shaw, Gupta \& Delery (2005) state that, in fact, several studies have shown that rotation negatively affects performance. For every employee that leaves a company, there are recruitment costs to find a replacement, loss of productivity costs due to the vacancy, and training costs needed to train a new employee. For jobs that pay less than $\$ 50,000$ per year, analysts have estimated that the cost of voluntary departure per employee is approximately $20 \%$ of that employee's annual salary. However, when it comes to executive rotation, the cost can increase dramatically, costing up to $213 \%$ of that employee's salary. The longer the firms kept their employees; there would be no need for additional expenses to train new employees. As such, employee retention was important for the company's long-term growth and success. Retaining the best employees would guarantee customer satisfaction and successful planning (Mello, 2006).

\section{Conceptual Framework}

The framework for this study is presented in Figure 1 below that shows the relationship between dependent variable and independent variables. 
Fig. 1: Conceptual Framework between contingent pay and Variable pay on employee performance.

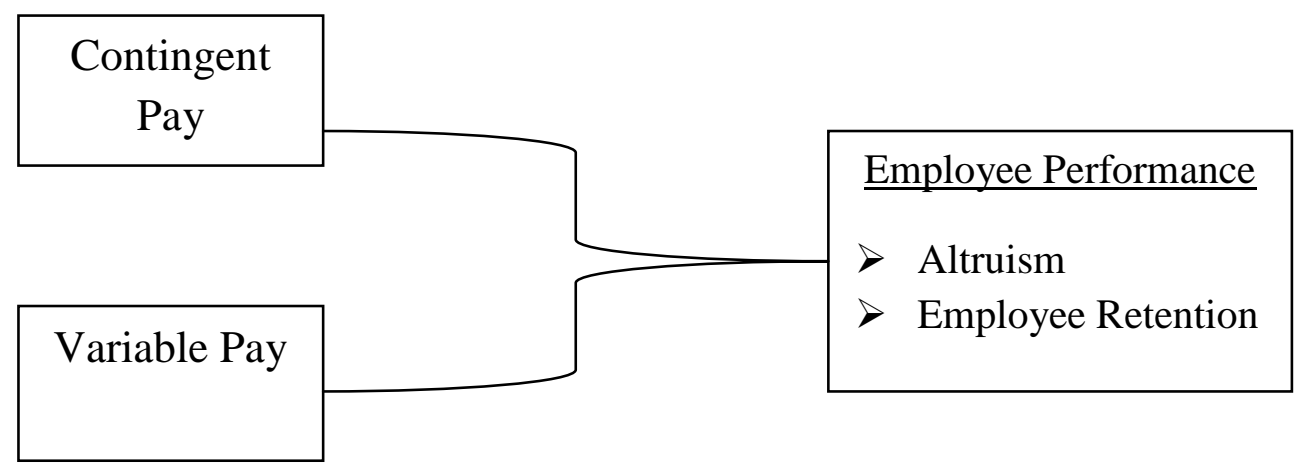

Based on the conceptual model, the study proposed the following hypotheses:

Ho1: There is no significant relationship existing between contingent pay and altruism in the selected public universities in Anambra State, Nigeria.

Ho2: There is no significant relationship existing between variable pay and employee retention in the selected public universities in Anambra State, Nigeria.

\section{Theoretical Framework}

This study is anchored on social exchange theory (SET) as proposed by George Homans in 1958; as the name implies, the main principles of the theory are exchange and reciprocity. The exchange in this context has to do with what an employee expects in exchange for what he has put into the organization in the form of innovative services, ideas and contributions, performance and productivity. Reciprocity within the context of this study deals with employees who return in equal measure to what he has received.

The exchanges here could be differently. On the part of the employees, it could be working overtime, being creative and ingenious, offering additional service and being proactive in dealing with problems. For organizations, exchanges could be in the form of sick leave, paid vacations, ensuring that things are done in an equitable and fair manner, paying based on skills and knowledge, recognition and equipment bonus. It could be in the form of economic or social exchanges. In addition to the variables of the study, when the contingent remuneration received by the teams of the organization corresponds to their effort, these team members would exhibit altruistic behaviours in reciprocity of what they receive. Similarly, when employees get a variable payment for good performance, they would like to pay if they remain faithful by staying longer in the organization.

\section{Empirical Review}

Rono \& Kiptum (2017) carried out a study whose purpose was to discover the factors that affect employee retention in an organization of the University of Eldoret. The findings revealed that 
compensation had a significant relationship with employee retention. Based on this, it was recommended that Eldoret University should ensure that the policy governing the level of compensation should be improved to improve a higher employee retention rate and should ensure the availability of a wide range of training, skills and professional development. It is a key factor of attraction and retention of employees. Ejumudo (2014) examined the management of the salary reward system and the performance of personnel in Nigeria; using the civil service of the state of Delta as a focus. The results of the study showed that the lack of funding for Delta State civil service wage system and the principles of equity, living costs and moderation, a culture rooted in low performance and the manner of entry of dysfunctional employees negatively affects staff performance. The study recommended the requirement of a fair, moderate and dynamic salary reward system that reflects the prevailing social costs of living, the dismantling of the lowperformance culture and a merit-based employee income practice.

Fapohunda (2010) investigated wage disparity and salary satisfaction of two universities in public and private sector universities in Nigeria. The results showed a disparity in remuneration between public and private academic staff with private universities that pay better than the public university. Salary satisfaction is low in both public and private universities. Working conditions in the two sectors differ; while those in the public sector have the benefits of job security, flexible work schedules, less supervision, freedom of association, lower workloads and clearer lines of communication, for those in the private sector, the payment package and promotional prospects are better, but job security is low, there is less freedom and heavier workloads. Therefore, it was recommended to close wage gaps; improvement in the level of salary satisfaction in public and private universities; constant improvement of working conditions and training and professional development opportunities. Payment and promotion policies should be reviewed to avoid stagnation.

Oyira, Regina, Nkamare, Lukpata, Uwa, \& Mbum (2015) investigated the effect of reward system on health care workers performance and revealed that monetary reward had a positive impact on employees' performance. This signifies that monetary reward influences performance positively and a reward or monetary reward that varies based on performance keeps an employee in the organization. Also, Mphil, Ramzan, Zubair, Ali \& Arslan (2014) examined the impact of compensation on employee performance revealed that compensation has a positive impact on employee performance. Compensation here could be in terms of varying bonuses in such a way as to align with performance and that as it influence performance, so also does it influence turnover intentions.

Simialrly, Sajuyigbe, Olaoye \& Adeyemi (2013) studied selected manufacturing companies in Ibadan Oyo State, Nigeria to examine the impact of reward on employees' performance came out with a related result. The result of their study showed that reward dimensions jointly predict employees' performance, which accounted for $71 \%$ variance in performance. Ndede (2014) explored the effect of reward management on employee performance in the hotel industry in Kenya and found a high correlation between reward management and employee performance. 


\section{METHODOLOGY}

A cross sectional survey research design was employed for this study given that data for the study was collected through questionnaire from sampled respondents. The population of the study consists of all the non-academic staff in the two selected universities. The study population from which the sample was drawn for the study consists of two public universities in Anambra State, Nigeria namely (Chukwuemeka Odumegwu Ojukwu University, Uli (COOU), and Nnamdi Azikiwe University, Awka (NAU). The population of the study depict that COOU has a total non-academic strength of 1879; and NAU has 2779 making it a total of 4658 staff. The sample size of the study was determined using Krejcie \& Morgan (1970) formula. Stratified sampling method was used in the selection of sampled respondents. An initial sample size of $n=354$ respondents was set, using the available historical information. However, 320 usable questionnaires were eventually collected and used in the data analysis, which gave an acceptable response rate of nearly $90.40 \%$. The data collection instrument was a five-point structured Likert questionnaire. The instrument was subjected to face and content validity to ensure that it measured what was intended. Data analysis was done through the use of Pearson's product moment correlation coefficient.

\section{DATA PRESENTATION AND ANALYSIS}

Research Question One: What is the nature of relationship existing between contingent pay and altruism in the selected public universities in Anambra State?

Table 1: Distribution of Responses for Contingent Pay and Altruism

\begin{tabular}{|l|l|l|l|l|l|l|l|l|}
\hline S/N & Questionnaire Items & $\begin{array}{l}\text { SA } \\
(5)\end{array}$ & $\begin{array}{l}\text { A } \\
(4)\end{array}$ & $\begin{array}{l}\text { UD } \\
(3)\end{array}$ & $\begin{array}{l}\text { D } \\
(2)\end{array}$ & $\begin{array}{l}\text { SD } \\
(1)\end{array}$ & Mean & Decision \\
\hline 1 & $\begin{array}{l}\text { Contingent Pay } \\
\text { The performances of teams are rewarded } \\
\text { based on the skill set of the members of } \\
\text { the teams. }\end{array}$ & 73 & 34 & 90 & 81 & 2.66 & Reject \\
\hline 2 & $\begin{array}{l}\text { The team reward in place in my } \\
\text { organization is flexible because better } \\
\text { performance attracts better rewards. }\end{array}$ & 55 & 69 & 21 & 77 & 94 & 2.73 & Reject \\
\hline 3 & $\begin{array}{l}\text { The abilities of the members of a team in } \\
\text { my firm are important because the bonus } \\
\text { they receive considers it. }\end{array}$ & - & 79 & 54 & 102 & 81 & 2.41 & Reject \\
\hline 4 & $\begin{array}{l}\text { There is added bonus attached to a team } \\
\text { that performs well in my organization. }\end{array}$ & 35 & 60 & 42 & 90 & 89 & 2.56 & Reject \\
\hline 5 & $\begin{array}{l}\text { The overall contribution of a team to the } \\
\text { organization is taken note of while } \\
\text { rewarding. }\end{array}$ & 47 & 59 & 49 & 100 & 61 & 2.78 & Reject \\
\hline & $\begin{array}{l}\text { Altruism } \\
\text { I will be motivated to help my team } \\
\text { members if I will get rewarded for doing } \\
\text { so. }\end{array}$ & 121 & 145 & - & - & 50 & 3.91 & Accept \\
\hline
\end{tabular}




\begin{tabular}{|l|l|l|l|l|l|l|l|l|}
\hline \hline 7 & $\begin{array}{l}\text { I can help my team members to do a better } \\
\text { job because the reward we receive is team- } \\
\text { based. }\end{array}$ & 90 & 121 & - & 45 & 60 & 3.43 & Accept \\
\hline 8 & $\begin{array}{l}\text { My team's performance will be better if } \\
\text { we can help each other to do a better job. }\end{array}$ & 59 & 37 & 60 & 117 & 43 & 2.85 & Reject \\
\hline 9 & $\begin{array}{l}\text { Our team performance will be enhanced } \\
\text { when we can cooperate better with each } \\
\text { other. }\end{array}$ & 60 & 22 & 34 & 130 & 70 & 2.68 & Reject \\
\hline 10 & $\begin{array}{l}\text { I am willing to go out of my way to help } \\
\text { my colleagues in my team because I know } \\
\text { that performance of my team will } \\
\text { enhance my reward. }\end{array}$ & 34 & 67 & 22 & 101 & 92 & 2.53 & Reject \\
\hline
\end{tabular}

Table 1 shows details of the distribution of responses and descriptive statistics for contingent pay and altruism in the selected public universities in Anambra State. The analysis is based on the mean of the individual questionnaire items and the threshold for accepting or rejecting a questionnaire item as being true or not in the institutions is $3(5+4+3+2+1=15 \div 5=3)$.

For the independent variable (contingent pay), when the respondents were asked if the performances of teams are rewarded based on the skill set of the members of the teams, they rejected it with a mean of 2.66. They also rejected that the team reward in place in their organization is flexible because better performance attracts better rewards with a mean of 2.73. Similarly, a mean of 2.41 shows that the respondents do not agree that the abilities of the members of a team in their firm are important because the bonus they receive considers it. A mean of 2.56 and 2.78 also indicates that the respondents did not agree that there is added bonus attached to a team that performs well in their organization and that the overall contribution of a team to the organization is taken note of while rewarding respectively.

On the dependent side of the variable in this section which is altruism, the respondents agreed that they will be motivated to help their team members if they will get rewarded for doing so with a mean of 3.91. They also agreed that they can help their team members to do a better job because the reward they receive is team-based with a mean of 3.43. They, however, rejected that their team's performance will be better if they can help each other to do a better job with a mean of 2.85 . Similarly, with a mean of 2.68 and 2.53 , the respondent rejected that their team performance will be enhanced when they can cooperate better with each other and that they are willing to go out of their way to help their colleagues in their team because they know that the performance of their team will enhance their reward respectively.

Research Question Two: What is the extent of relationship existing between variable pay and employee retention in the selected public universities in Anambra State? 
International Journal of Advanced Academic Research (Social and Management Sciences) | ISSN: 2488-9849

Journal DOI: 10.46654/ij.24889849

Vol. 6, Issue 12 (December, 2020) | www.ijaar.org

Article DOI: 10.46654/ij.24889849.s61230

Table 4.2: Distribution of Responses for Variable Pay and Employee Retention

\begin{tabular}{|c|c|c|c|c|c|c|c|c|}
\hline $\mathrm{S} / \mathrm{N}$ & Questionnaire Items & $\begin{array}{l}\text { SA } \\
\text { (5) }\end{array}$ & $\begin{array}{l}\text { A } \\
\text { (4) }\end{array}$ & $\begin{array}{l}\text { UD } \\
\text { (3) }\end{array}$ & $\begin{array}{l}\text { D } \\
\text { (2) }\end{array}$ & $\begin{array}{l}\text { SD } \\
\text { (1) }\end{array}$ & Mean & Decision \\
\hline & Variable pay & & & & & & & \\
\hline 1 & $\begin{array}{l}\text { People in my organization do not receive } \\
\text { the same pay as it varies based on } \\
\text { performance. }\end{array}$ & - & 34 & 49 & 117 & 116 & 2.00 & Reject \\
\hline 2 & $\begin{array}{l}\text { The reward we receive in my } \\
\text { organization is flexible in that it depends } \\
\text { on individual skill-set. }\end{array}$ & 12 & 23 & 39 & 242 & - & 2.38 & Reject \\
\hline 3 & $\begin{array}{l}\text { The better the performance of people in } \\
\text { my workplace, the greater the reward } \\
\text { they are likely to receive. }\end{array}$ & - & 45 & 67 & 128 & 76 & 2.26 & Reject \\
\hline 4 & $\begin{array}{l}\text { The performance of employees is not } \\
\text { considered while rewarding in my } \\
\text { organization. }\end{array}$ & 121 & 94 & 12 & 89 & - & 3.78 & Accept \\
\hline \multirow[t]{2}{*}{5} & $\begin{array}{l}\text { Everybody is paid according to what } \\
\text { he/she is supposed to receive irrespective } \\
\text { of your performance. }\end{array}$ & 161 & 121 & 22 & 10 & 2 & 4.36 & Accept \\
\hline & Employee Retention & & & & & & & \\
\hline 6 & $\begin{array}{l}\text { I will stay long in my organization if my } \\
\text { skills are well appreciated. }\end{array}$ & 123 & 87 & 2 & 104 & - & 3.72 & Accept \\
\hline 7 & $\begin{array}{l}\text { I do not want to leave my organisation } \\
\text { because my competencies are well } \\
\text { appreciated within my organization. }\end{array}$ & 56 & 78 & 12 & 90 & 80 & 2.81 & Reject \\
\hline 8 & $\begin{array}{l}\text { I will quit my job because my efforts are } \\
\text { not properly acknowledged in my } \\
\text { organization. }\end{array}$ & 89 & 101 & - & 121 & 5 & 3.47 & Accept \\
\hline 9 & $\begin{array}{l}\text { My organization will lose my services } \\
\text { once I get an opportunity to leave to other } \\
\text { organizations. }\end{array}$ & 101 & 57 & - & 67 & 91 & 3.03 & Accept \\
\hline 10 & $\begin{array}{l}\text { Leaving my firm does not appeal to me } \\
\text { as I am well rewarded here. }\end{array}$ & 19 & 98 & - & 178 & 21 & 2.73 & Reject \\
\hline
\end{tabular}

Table 2 shows the distribution of responses and descriptive statistics for variable pay and employee retention in the selected public universities in Anambra State. The mean of the individual questionnaire items was used to ascertain whether cumulatively, they agree to or reject a questionnaire item. The benchmark for acceptance is $3(5+4+3+2+1=15 \div 5=3)$.

Starting with the independent variable (variable pay), the respondents rejected the notion that people in their organization do not receive the same pay as it varies based on performance with a mean of 2.00. They also rejected that the reward they receive in their organization is flexible in that it depends on individual skill-set with a mean of 2.38. On the same wavelength, they rejected that the better the performance of people in their workplace, the greater the reward they are likely to receive 
with a mean of 2.26. They, however, accepted that the performance of employees is not considered while rewarding in their organization with a mean of 3.78. They almost unanimously agreed that everybody is paid according to what he/she is supposed to receive irrespective of their performance with a mean of 4.36 .

In the dependent angle of this section, the respondents agreed that they will stay long in their organization if their skills are well appreciated with a mean of 3.72. They rejected that they do not want to leave their organisation because their competencies are well appreciated within their organization with a mean of 2.81 . They agreed with a mean of 3.47 that they will quit their job because their efforts are not properly acknowledged in their organization. They also agreed that their organization will lose their services once they get an opportunity to leave to other organizations with a mean of 3.03. They rejected that leaving their firm does not appeal to them as they are well rewarded in it 2.73

\section{Test of Hypotheses}

\section{Hypothesis One:}

$\mathrm{Ho}_{1}$ : There is no significant relationship existing between contingent pay and altruism in the selected public universities in Anambra State.

Table 3: Correlation Analysis for Contingent Pay and Altruism

\section{Correlations}

\begin{tabular}{|l|l|l|l|}
\hline \multicolumn{2}{|c|}{} & Contingent Pay & Altruism \\
\hline Contingent Pay & Pearson Correlation & 1 & $.968^{* *}$ \\
\cline { 2 - 4 } & Sig. (2-tailed) & & .000 \\
\cline { 2 - 4 } & $\mathrm{N}$ & 320 & 320 \\
\hline \multirow{3}{*}{ Altruism } & Pearson Correlation & $.968^{* *}$ & 1 \\
\cline { 2 - 4 } & Sig. (2-tailed) & .000 & 320 \\
\cline { 2 - 4 } & $\mathrm{N}$ & 320 & \\
\hline
\end{tabular}

**. Correlation is significant at the 0.01 level (2-tailed).

Table 3 shows the correlation analysis carried out on contingent pay and altruism in the selected public universities in Anambra State. The correlation coefficient obtained was .968 which shows that the relationship is positive and very strong.

Table 4: Significance test for hypothesis one

\begin{tabular}{|l|l|l|l|l|}
\hline $\mathrm{N}$ & Cal. R & Df & Crit. r. & Remark \\
\hline 320 & .968 & 318 & 0.098 & Significant \\
\hline
\end{tabular}


International Journal of Advanced Academic Research (Social and Management Sciences) | ISSN: 2488-9849

Table 4 reveals the test of significance for hypothesis one. It showed that at $5 \%$ level of significance and at 318 degrees of freedom, that the critical $\mathrm{r}$ is 0.098 and the calculated $\mathrm{r}$ is .968 (cal. $\mathrm{r} .968$ > crit. $r$ 0.098). Therefore, the research hypothesis is accepted.

\section{Hypothesis Two:}

$\mathrm{Ho}_{2}$ : There is no significant relationship existing between variable pay and employee retention in the selected public universities in Anambra State.

Table 5: Correlation Analysis for Variable pay and Employee Retention

\begin{tabular}{|l|l|l|l|}
\hline \multicolumn{2}{|l|}{ Correlations } & Variable Pay & Employee Retention \\
\hline \multirow{4}{*}{ Variable Pay } & Pearson Correlation & 1 & $.964^{* *}$ \\
\cline { 2 - 4 } & Sig. (2-tailed) & & .000 \\
\cline { 2 - 4 } & $\mathrm{N}$ & 320 & 320 \\
\hline \multirow{2}{*}{$\begin{array}{l}\text { Employee } \\
\text { Retention }\end{array}$} & Pearson Correlation & $.964^{* *}$ & 1 \\
\cline { 2 - 4 } & Sig. (2-tailed) & .000 & 320 \\
\cline { 2 - 4 } & $\mathrm{N}$ & 320 & \\
\hline$* *$ Correlation is significant at the 0.01 level (2-tailed). & \\
\cline { 2 - 4 } &
\end{tabular}

Table 5 shows the correlation analysis carried out on variable pay and employee retention in the selected public universities in Anambra State. The correlation coefficient obtained was .964 indicating a very strong positive relationship.

Table 6: Significance test for hypothesis two

\begin{tabular}{|l|l|l|l|l|}
\hline $\mathrm{N}$ & Cal. R & Df & Crit. r. & Remark \\
\hline 320 & .964 & 318 & 0.098 & Significant \\
\hline
\end{tabular}

Table 6 shows the test of significance for hypothesis two. It showed that at 5\% level of significance and at 318 degrees of freedom, that the critical $r$ is 0.098 . Given that the calculated $r .964$ is greater than the critical r (cal. r .964 > crit. r 0.098), the research hypothesis is therefore accepted.

\section{Discussion of Findings}

In the analysis of the first hypothesis carried out with the use of Pearson's correlation analysis, the findings led to the acceptance of the alternate hypothesis, and thus indicate that there is a significant relationship existing between contingent pay and altruism in the selected public universities in Anambra State, Nigeria. This result signifies that when a reward given out is hinged on a certain level of performance, then the employees will be willing to exhibit tendencies of helping behaviour (altruism). When teams reward hinges on how they performed their assigned tasks, then members of the team will be willing to help each other so as to perform better in other to attract better rewards 
from the organization. But when the reward is a blanket reward where people or teams are paid and given bonuses whether they performed well or not, such a situation will lead to the reluctance of employees or staff to put in a good effort geared towards making the organization performs well generally. This result aligns with the study of Ndede (2014) who explored the effect of reward management on employee performance in the hotel industry in Kenya and found a high correlation between reward management and employee performance. When reward in the organization is managed properly by hinging rewards on performance, then the performance of employees will be enhanced by making the employees willing to help one another in their jobs. Also, the findings of Nnaji-Ihedinmah \& Egbunike (2015) who carried out a study to determine whether a relationship exists between reward system and employee performance of commercial banks in Anambra State of Nigeria corroborates with this work. The findings indicated the presence of a relationship between rewards and employee performance. That is, a properly handled and managed reward system enhances employee performance.

From the test of the second hypothesis, it was revealed that there is a significant relationship existing between variable pay and employee retention in the selected public universities in Anambra State, Nigeria. This entails that when pay or reward changes based on performance or lack of it, it will influence employee retention in the organization. Staff will love to stay in a place where they are sure that with better performance comes better pay and may be forced to work hard to get better pay if they do not work hard hitherto. Aligning with this study is that of Oyira, Regina, Nkamare, Lukpata, Uwa, \& Mbum (2015) who examined the effect of reward system on health care workers performance and showed that pay have a positive effect on the performance employees. This signifies that monetary reward influences performance positively and a reward or monetary reward that varies based on performance keeps an employee in the organization.

Also, Mphil, Ramzan, Zubair, Ali \& Arslan (2014) who measured the impact of compensation on employee performance revealed that compensation has a positive impact on employee performance. Compensation here could be in terms of varying bonuses in such a way as to align with performance and that as it influences performance, so also does it influence turnover intentions. Simialrly, Sajuyigbe, Olaoye \& Adeyemi (2013) who studied selected manufacturing companies in Ibadan, Oyo State, Nigeria to examine the impact of reward on employees' performance came out with a related result. The result of their study showed that reward dimensions jointly predict employees' performance, which accounted for $71 \%$ variance in performance.

\section{CONCLUSION AND RECOMMENDATIONS}

The study concludes that contingent pay and variable pay has a significant positive relationship with employee performance variables (altruism and employee retention) in public universities studied in Anambra State Nigeria. However, based on the findings and conclusion of the study the following recommendations were made:

1) Team pay should take into account the performance of several team members as individuals and as a group, as it will make team members contribute to the maximum exit of the team by making members eager to help each other to perform best.

2) The administration of the universities studied must take into account the performance of people when granting pay system, as this will help them to motivate employees to try their best and stay longer in organizations. 


\section{REFERENCE}

Appelbaum, S.H., \& Shapiro, B.T. (1991). Pay for Performance: Implementation of Individual and Group Plans, Journal of Management Development, 10(7), 30-40.

Appelbaum, S.H., \& Shapiro, B.T. (1992). Pay for Performance: Implementation of Individual and Group Plans, Management Decision, 30(6), 86-91.

Aquinis, H. (2007). Performance management, Upper Saddle River, New Jersey: Pearson Hall.

Arachie, A.E. (2016). Organizational Citizenship Behaviour and Performance of selected Commercial Banks in Anambra State. A Thesis Presented to the Department of Business Administration, Faculty of Management Sciences, Nnamdi Azikiwe University, Awka in Partial Fulfilment of the Requirements for the Award of Master of Science (M.sc) Degree in Business Administration.

Armstrong, M. (2012). Armstrong's Handbook of Human Resource Management Practice. New York, NY: Kogan Page Publishers.

Armstrong, M., \& Murlis, H. (2007). Reward Management: A Handbook of Remuneration Strategy and Practice. London, Kogan Page Limited.

Arrowsmith, J., Nicholaisen, H., Bechter, B., \& Nonell, R. (2010). The management of variable pay in European banking, The International Journal of Human Resource Management, 21(15), 2716-2740.

Berridge C. (2001). Reward Learning; Reinforcements, incentives and expectations, The Psychology of Learning and Motivation, 40, 17-31.

Burns, T., \& Carpenter, J. (2008). Organizational Citizenship and Student Achievement. Journal of Cross Disciplinary Perspectives in Education, 1(1), 51 - 58.

Colling, T., \& Terry, M. (2010). Work, the employment relationship and the field of industrial relations. In: Colling, Trevor and Terry, Michael, (eds.) Industrial relations: theory and practice. Industrial Relations Series, Chichester, West Sussex, U.K.: John Wiley \& Sons, 326.

Dale-Olsen, H. (2012). Sickness absence, performance pay and teams, International Journal of Manpower, 33(3), 284-300.

Ejumudo, K.B.O. (2011). Performance Appraisal in the Delta State Civil Service. Journal of Management, 5(2), 21-28.

Ejumudo, K.B.O. (2014). Pay Reward System Management and Staff Performance in Nigeria: A Study of the Delta State Civil Service. Public Policy and Administration Research, 4(9), 8094. 
International Journal of Advanced Academic Research (Social and Management Sciences) | ISSN: 2488-9849

Journal DOI: 10.46654/ij.24889849

Vol. 6, Issue 12 (December, 2020) | www.ijaar.org

Article DOI: 10.46654/ij.24889849.s61230

Eriksson, T. \& Villeval, M.C. (2008). Performance-pay, sorting and social motivation. Journal of Economic Behaviour \& Organization, 68(2), 412-421.

Fapohunda, T.M. (2010). Pay Disparity and Pay Satisfaction in Public and Private Universities in Nigeria. European Scientific Journal, 8(28), 122-135.

Felps, W., Mitchell, T.R., Hekman, D.R., Lee, T.W., Holtom, B.S., \& Harman, W.S. (2009). Turnover Contagion: How Co-workers' Job Embeddedness and Job Search Behaviours Influence Quitting. Academy of Management Journal, 52(3), 545-561.

Gerhat, .C. \& Milkovich, G. (1992). Performance pay as a competitive weapon. New York: Wiley Inc.

Gould-Williams, J. (2003). 'The importance of HR practices and workplace trust in achieving superior performance: a study of public-sector organizations'. International Journal of Human Resource Management, 14: 1, 28-54.

Harzing, A.W., \& Ruysseveldt, J.V., (2005). International Human Resource Management, London, SAGE Publication Ltd.

Hashim J. (2000). Human resource development practices as determinant of HRD climate and quality orientation. Journal of European Industrial Training, 30(1), 4-18.

Heneman, R.L. (2002). Strategic Reward Management: Design, Implementation, and Evaluation, Greenwich, CT: Information Age Publishing.

Horváthová, P., Davidová, M., \& Bendová, M. (2012). Contingent Pay and Experience with its use by Organizations of the Czech Republic Operating in the Field of Environmental Protection. International Scholarly and Scientific Research \& Innovation 6(4), 522-526.

Kemboi, A., Geoffrey, B.K., \& Keter, C.J, (2014). Intellectual Capital as an Antecedent to Employee Performance in Commercial Banks in Eldoret Town, Kenya, Developing Country Studies, vol. 4(4), $34-44$.

Korir, I., \& Kipkebut, D. (2016). The Effect of Reward Management on Employees Commitment in the Universities in Nakuru County-Kenya. Journal of Human Resource Management, 4(4), 37-48. doi: 10.11648/j.jhrm.20160404.12.

Krejcie, R.V., \& Morgan, D.W. (1970). Determining Sample Size for Research Activities. Educational and Psychological Measurement, 30, 607-610.

Mamoria, C.B. (1991). Personnel Management. Bombay: Himalaya Publishing House.

Mello, J.A. (2006). Strategic Human Resource Management. $2^{\text {nd }}$ Edition, Thomson, Mason, OH: 213-320.

Michael, M.P. \& Heneman, R.L. (2000). Contextual Determinants of Variable Pay Plan Design: A Proposed Research Framework, Human Resource Management Review, 10(3), 289-305. 
International Journal of Advanced Academic Research (Social and Management Sciences) | ISSN: 2488-9849

Journal DOI: 10.46654/ij.24889849

Vol. 6, Issue 12 (December, 2020) | www.ijaar.org

Article DOI: 10.46654/ij.24889849.s61230

Milkovich, G. \& Newman, J. (2002). Compensation, 7th ed. Homewood, IL. McGraw-Hill Higher Education.

Milkovich, G.F \& Newman, J.M. (2001). Compensation Approach. Boston: Irwin Inc.

Mphil, A.H., Ramzan, M.R. Zubair, H.M., Ali, G.A., \& Arslan, M.A. (2014). Impact of Compensation on Employee Performance (Empirical Evidence from Banking Sector of Pakistan. International Journal of Business and Social Science, 5(2), 302-309.

Ndede, H.O. (2014). Effects of Reward Management on Employee Performance in Hotels in North Coast, Kenya. A Research Project Submitted in Partial Fulfilment of the Requirements for the Award of the Degree of Master of Business Administration (MBA), School of Business, University of Nairobi.

Njanja, W.L., Maina, R.N., Kibet, L.K., \& Njagi, K. (2013). Effect of Reward on Employee Performance: A Case of Kenya Power and Lighting Company Ltd., Nakuru, Kenya. International Journal of Business and Management, 8(21), 41-49.

Nnaji-Ihedinmah, N.C., \& Egbunike, F.C. (2015). Effect of Rewards on Employee Performance in Organizations: A Study of Selected Commercial Banks in Awka Metropolis. European Journal of Business and Management, 7(4), 80-88.

Obaniro K., Oluseye, O., \& Osibanjo O.A. (2014). Organizational Citizenship Behaviour, Hospital Corporate Image and Performance. Journal of Competitiveness 6(1), 36 - 49.

Obisi C. (2003). Organizational Behaviour; Concepts and Applications, Lagos: Malthouse Press.

Ogbonnaya, C., Daniels, K. \& Nielsen, K.M. (2017). Does contingent pay encourages positive employee attitudes and intensify work? Human Resource Management Journal, 27 (1), 94112. DOI: $10.1111 / 1748-8583.12130$.

Oyira, E.J., Regina, R., Nkamare, S.E., Lukpata, F.E., Uwa1, S.L., \& Mbum, P.A. (2015). Effect of reward system among health care workers performance: a case study of university of Calabar teaching hospital Calabar, Nigeria. Journal of Hospital Administration, 4(3), 45-53.

Redman, T., \& Snape, E. (2005). I to Wed: The role of consciousness transformation in compassion and Altruism. Journal of Management Studies, 42(2), 2200-2380

Rono, E.J. \& Kiptum, G.K. (2017). Factors Affecting Employee Retention at the University of Eldoret, Kenya. Journal of Business and Management, 19(3), 109-115.

Roshna \& Rohan (2016). Analyzing Role of Reward Management System on Managing Employee Performance Effectively: Study with reference to Co-operative Sugar factories in Pune, Maharashtra. Chronicle of the Neville Wadia Institute of Management Studies \& Research, 46-53. 
Sajuyigbe, A.S., Olaoye, B.O., \& Adeyemi, M.A. (2013). Impact of Reward on Employees Performance in a Selected Manufacturing Companies in Ibadan, Oyo State, Nigeria. International Journal of Arts and Commerce, 2(2), 27-32.

Shaw, J.D. Gupta, N. \& Delery, J.E., (2005). Alternative conceptualizations of the relationship between voluntary turnover and organizational performance. Academy of Management Journal, 48, 50-68.

Shield, J. (2007). Managing Employee Performance and Reward. Cambridge. Cambridge University Press.

Turinawe, H. (2011). Reward Systems, Job Satisfaction, Organizational Commitment and Employee Performance in Public Higher Institutions of Learning in Uganda. A Dissertation Submitted to Makerere University Business SCHOOL is Partial Fulfilment of the Requirements for the award of a Master's Degree of Human Resource Management of Makerere University.

Tuvei, D., Wanjere, D., \& Mauyo, H. (2016). Influence of Intrinsic Rewards on Organizational Performance in Sugar Companies of Western Kenya. International Journal of Science and Technology, 6(10).

Yen, H.R., \& Niehoff, B.P. (2004). Organizational citizenship behaviours and organizational effectiveness: Examining relationships in Taiwanese banks. Journal of Applied Social Psychology, 34, (8), 1617-1637.

Zhou, J., Qian, X., Henan, Q., \& Lei, X. (2009). Total reward strategy: A human resources management strategy going with the trend of the times, International Journal of Business and Management, 4(11): 177-183. 